\title{
The Antiinfective Effects of Velvet Antler of Formosan Sambar Deer (Cervus unicolor swinhoei) on Staphylococcus aureus-Infected Mice
}

\author{
Ting-Yeu Dai, ${ }^{1}$ Chih-Hua Wang, ${ }^{2}$ Kun-Nan Chen, ${ }^{3}$ I-Nung Huang, ${ }^{1}$ Wei-Sheng Hong, \\ Sheng-Yao Wang, ${ }^{1}$ Yen-Po Chen, ${ }^{1}$ Ching-Yun Kuo, ${ }^{4}$ and Ming-Ju Chen ${ }^{1,5}$ \\ ${ }^{1}$ Department of Animal Science and Technology, National Taiwan University, No. 50 Lane 155 Sec. 3 Keelung Road, Taipei 106, Taiwan \\ ${ }^{2}$ Kaohsiung Animal Propagation Station, Livestock Research Institute, Council of Agriculture, Kaohsiung, Taiwan \\ ${ }^{3}$ Department of Mechanical Engineering, Tungnan University, Taipei 222, Taiwan \\ ${ }^{4}$ Livestock Research Institute, Council of Agriculture, Tainan, Taiwan \\ ${ }^{5}$ Center for Biotechnology, National Taiwan University, No. 81, Changxing, Taipei 106, Taiwan
}

Correspondence should be addressed to Ching-Yun Kuo, chingyunkuo@gmail.com and Ming-Ju Chen, cmj@ntu.edu.tw

Received 15 November 2010; Accepted 2 February 2011

Copyright () 2011 Ting-Yeu Dai et al. This is an open access article distributed under the Creative Commons Attribution License, which permits unrestricted use, distribution, and reproduction in any medium, provided the original work is properly cited.

\begin{abstract}
We assayed the effects of velvet antler (VA) of Formosan sambar deer (Cervus unicolor swinhoei) and its extracts on the antiinfective activity against pathogenic Staphylococcus aureus in vitro and in vivo in this study. In vitro data indicated that the VA extracts stimulated the proliferation of resting splenocytes and macrophages in a dose-dependent manner up to the highest concentration used $\left(150 \mu \mathrm{g} \mathrm{mL} L^{-1}\right)$. The production of proinflammatory cytokines (TNF- $\alpha$, IL-6, IL-12) by lipoteichoic acid was significantly suppressed after being cocultured with the VA extracts in a dose-dependent manner. Animal test in S. aureus-infected mice demonstrated that the numbers of bacteria determined in the kidneys and peritoneal lavage fluid of $S$. aureus-infected mice were significantly higher than those found in the same organs of mice pretreated with the VA samples. Moreover, the highly enhanced phagocytic activity of macrophages was further verified after in vitro treatment with the VA samples. The protective mechanisms of the VA samples might include an immune enhancer and an inflammatory cytokine suppressor.
\end{abstract}

\section{Introduction}

Formosan sambar deer (Cervus unicolor swinhoei) is an indigenous subspecies in Taiwan [1]. The use of its antler velvet has also steadily increased since the start of deer farming in Taiwan in 1963. Velvet antler (VA), the unossified antler of Family Cervidae, has been used in traditional Chinese medicines and healthy food for over 2000 years [2]. There are many different carbohydrates, peptides, lipids, sterols, and inorganic substances $(\mathrm{Ca}, \mathrm{Zn}, \mathrm{Pb})$ in $\mathrm{VA}$, which contains many different carbohydrates, peptides, lipids, sterols, and inorganic substances $(\mathrm{Ca}, \mathrm{Zn}, \mathrm{Pb})[3,4]$, should be beneficial to health. Many reports and clinical observations convincingly show that VA and its extracts are composed of many compounds with different functional groups, such as epidermal growth factor [5], proteoglycans with a hyaluronic acid core [6], and some water soluble compounds (carbohydrates, hexosamines, hydronyprolines, mucopolysacchride, sialic acids, uronic acids) as well as water insoluble fatty acids (prostaglandins, phospholipids, glycolipids, and gangliosides) [4]. Those active compounds may be the reasons of inhibitory activities on arthritis $[7,8]$, immunomodulatory activities [9], antinarcotic effects [10], and inhibitory action on monoamine oxidase [2]. Recent studies have shown that polysaccharides and lysophosphatidylcholines are responsible for antiulcer and hypertensive actions, respectively [11]. It has also been reported that the phosphates and gangliosides of VA can ease the symptoms of senility $[12,13]$.

It is widely believed that VA and its extracts have immunomodulatory activities. It was reported that orally administrated VA extracts increased monocytes in rats [14]. Their increase may enhance immune function. Intraperitoneal injection of pantocrin enhanced phagocytosis and immunoglobulin levels in mice [15]. Suh et al. [16] examined ethanol extracts from antlers of Cervus nippon, which enhanced the phagocytic activity of murine peritoneal macrophages. 
Kim et al. [9] further identified the active compounds and suggested that phosphatidylcholines with saturated fatty acyl chains might be immunostimulating factors. In addition, VA extracts have been used in the prevention and treatment of certain immune-related diseases, such as rheumatoid arthritis. Since some researches provide evidences that velvet antler might effectively relieve inflammation in vitro and in vivo [17], VA might have the potential to be used as possible remedy to treat septic syndrome. However, there is a lack of evidence for antiinfective effects of VA and its extracts. The underlying mechanisms are also fairly unknown.

Staphylococcus aureus is a major human pathogen that causes various types of infections and disease syndromes. It is the most familiar Gram-positive pathogen that produces a wide array of toxins [18]. Infection with S. aureus may cause severe sepsis and lead to septic shock. It will be considered as an appropriate bacterium in infection model [19]. Thus, the purpose of this study was to evaluate the effects of VA of Formosan sambar deer and its extracts on the antiinfective activities against pathogenic $S$. aureus in vitro and in vivo.

\section{Materials and Methods}

2.1. VA Samples. VA from Formosan sambar deer was harvested in Kaohsiung Animal Propagation Station, Taiwan Live Stock Research Institute (Pintong, Taiwan) after a 75-day VA growing period. Fresh VA was immediately sliced and frozen at $-20^{\circ} \mathrm{C}$. The frozen VA slices were dehydrated by lyophilization (Freeze dryer, Kingmech Co. Ltd., Taipei, Taiwan) and then grinded into fine powder (VA powder) less than 100 mesh by pulverizing machine (No. RT-02A, Rong Tsong Co., Taichung, Taiwan). The VA cold-watersoaked extract (VACWS extract) was obtained by soaking the VA powder with cold distilled water $\left(50 \mathrm{~g} \mathrm{~L}^{-1}\right)$ and stirring with a magnetic stir bar at $4^{\circ} \mathrm{C}$ for $24 \mathrm{hrs}$. The VA water-boiled-extract (VAWB extract) was conducted by cooking the VA powder with boiling distilled water $\left(50 \mathrm{~g} \mathrm{~L}^{-1}\right)$ for $6 \mathrm{hrs}$. After the soaking and boiling process, the VA extracts were centrifuged $(1000 \times \mathrm{g}, 10 \mathrm{~min})$, and the insoluble components were discarded. The VA extracts were then freeze-dried and stored at $-20^{\circ} \mathrm{C}$.

For in vitro assays, the dehydrated VA extracts were dissolved in Dulbecco's phosphate buffered saline (DPBS; Thermo Fisher Scientific Inc., Logan, UT, U.S.A.) and sterilized by passing through $0.22 \mu \mathrm{m}$ filters (Millipore Corp., Carrigtwohill, Ireland). The extract samples were dissolved and diluted immediately before the assays were performed.

2.2. Experimental Animals. Six-week-old female BALB/ cByJNarl mice (National Laboratory Animal Center; NLAC, Taipei, Taiwan) were accustomed to their new environment for at least 1 week before the start of the experiment. The mice were maintained in an automatic light/dark cycle (light periods of $14 \mathrm{hrs}$ ). Temperature and humidity were kept constant at $22^{\circ} \mathrm{C}$ and $50 \%$, respectively. The animal care and treatment were performed in accordance with the guidelines of the National Science Council of Republic of China.

2.3. Cell Cultures. The murine macrophage cell line RAW 264.7 (ATCC TIB-71), obtained from Bioresource Collec- tion, and Research Center (BCRC, HsinChu, Taiwan), was cultured in a complete Dulbecco's Modified Eagle's Medium (DMEM; Thermo) supplied with 10\% heat-inactivated fetal bovine serum (hFBS; Invitrogen, Carlsbad, CA, U.S.A.) and $1 \%$ antibiotics (Antibiotic-Antimycotic; Invitrogen). The cells were maintained in $95 \%$ air with $5 \% \mathrm{CO}_{2}$ at $37^{\circ} \mathrm{C}$ in a humidified incubator (Revco, Santa Fe Springs, CA., U.S.A.).

For splenocytes, the mice were sacrificed by cervical dislocation and splenocytes were harvested for culture. The preparation of splenocyte cultures was based on the procedure as described by Zhao et al. [20]. Murine peritoneal cells were isolated from seven-week-old female BALB/cByJNarl mice (NLAC) as previously described by Zhang et al. [21] and Hong et al. [22]. Cell number and viability were enumerated by $0.4 \%$ trypan blue stain (Invitrogen) exclusion on a hemacytometer (Superior, Marienfeld, Germany) using an inverted microscope (Olympus Optical Co. Ltd., Tokyo, Japan).

2.4. Pathogenic S. aureus. Pathogenic S. aureus subsp. aureus Rosenbach (BCRC12651) was propagated in tryptic soy broth (BD DifcoTM) and incubated at $37^{\circ} \mathrm{C}$. The bacterial counts of $S$. aureus were determined by a 10 -fold series dilution with $0.85 \%$ saline, and $0.1 \mathrm{~mL}$ of dilution were cultured on blood agar plate (Creative Media Products, Ltd., Taipei, Taiwan) at $37^{\circ} \mathrm{C}$ for $24 \mathrm{hrs}$.

2.5. S. aureus-Infected Mice Model. Specific pathogen-free female 6-week-old BALB/cByJNarl mice (NLAC) were divided into groups $(n=5-8)$, each of which were intragastrically (i.g.) administrated with distilled water $\left(200 \mu \mathrm{L} \mathrm{mouse}^{-1}\right)$, the VA extracts $\left(200 \mu \mathrm{L}\right.$ mouse $\left.^{-1}\right)$, or the VA powder (0-500 $\mathrm{mg} \mathrm{kg}^{-1}$ mouse body weight), respectively, each day for 28 days. The mice were then i.p. infected with $1.5 \times 108 \mathrm{cfu}$ mouse ${ }^{-1}$ live pathogenic $S$. aureus cells suspended in $200 \mu \mathrm{L}$ of DPBS.23. After 48 -hr pathogenic injection, blood was collected by cheek punch with animal bleeding lancet (GoldenRod $5.0 \mathrm{~mm}$ point size; MEDIpoint Inc., Mineola, New York, U.S.A.) and Microtainer tubes (BD, Franklin Lakes, NJ., U.S.A.) containing clot activator and polymer gel. The infected mice were then sacrificed by cervical dislocation and injected $10 \mathrm{~mL}$ of cold DPBS into the peritoneal cavity. Peritoneal lavage fluid (PLF), kidneys and spleen of infected mice were also collected for further measurement of organs' weight and bacterial counts. The blood was centrifuged $\left(25^{\circ} \mathrm{C}, 10,000 \times \mathrm{g}, 5 \mathrm{~min}\right)$. The serum was separated and stored at $-80^{\circ} \mathrm{C}$ for cytokine assays.

2.6. Cell Proliferation Assay. RAW 264.7 cells and murine splenocytes were cultured in sterile 96-well flat-bottomed plates (TPP, Trasadingen, Switzerland) $\left(5 \times 10^{3}\right.$ cells well $\left.^{-1}\right)$ with or without the VA extracts ( 25 to $150 \mu \mathrm{g} \mathrm{mL}^{-1}$ ) and incubated at $37^{\circ} \mathrm{C}$ for $12 \mathrm{hrs}$. Ten $\mu \mathrm{g} \mathrm{mL}^{-1}$ of lipoteichoic acid (LTA; Sigma, St. Louis, MN., U.S.A.) was used as a positive control. Cell proliferation assay was performed by BrdU Cell Proliferation kit (Colorimetric; Roche, Mannheim, Germany) according to manufacturer's instruction. 


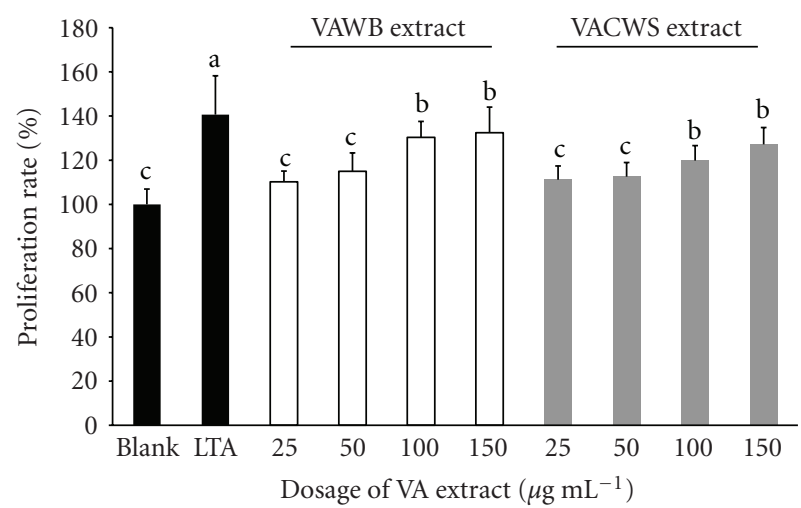

(A) RAW264.7 cells

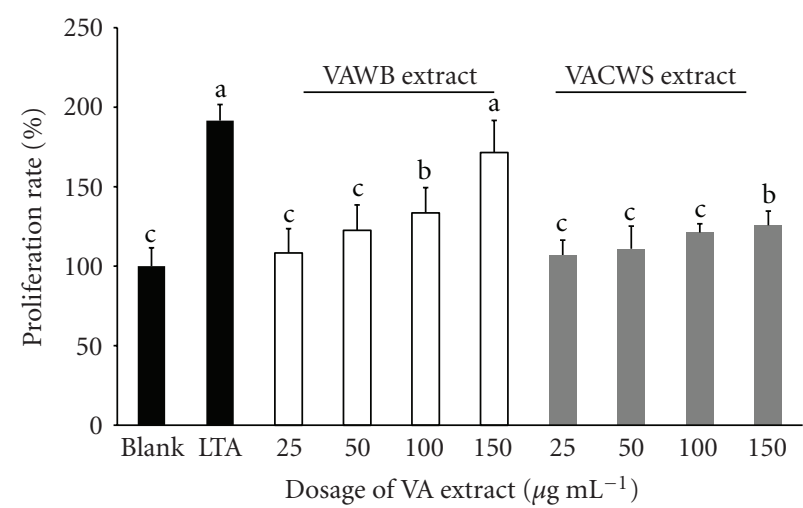

(B) Splenocytes

FIgure 1: The VA extracts enhance cell proliferation activities in (A) RAW 264.7 cells; (B) splenocyte. Proliferation rate were calculated by the absorbance value of blank group as $100 \%$. Each experimental value was divided with the absorbance value of blank group. Values are mean \pm S.E.M. Asterisk denotes values that are significantly different from positive control group (LTA group). (a-c) Means within the same column without the same superscripts differ significantly $(P<.05, n=5)$.

2.7. Cytokine Assays. RAW 264.7 cells and the murine peritoneal cells were plated to 24-well flat-bottomed plate (BD FalconTM, Franklin Lakes, NJ, U.S.A.) $\left(2 \times 10^{5}\right.$ cells well $\left.^{-1}\right)$ and cocultured in the VA extracts ( 25 to $200 \mu \mathrm{g} \mathrm{mL}^{-1}$ ) with or without $10 \mu \mathrm{g} \mathrm{mL}{ }^{-1} \mathrm{LTA}$ at $37^{\circ} \mathrm{C}$ for $24 \mathrm{hrs}$. The cytokine levels of murine tumor necrosis factor (TNF)- $\alpha$, interleukin (IL) -6 and IL-12 p40 in cell supernatant and IL-6 and transforming growth factor (TGF)- $\beta 1$ in mice sera were measured by Duoset sandwich ELISA kit (R\&D Systems, Minneapolis, MN, U.S.A.) according to manufacturer's instruction. The results were expressed as the concentration of each cytokine.

2.8. Phagocytosis Assay. Fluorescein-isothiocyanate-(FITC)labeled $S$. aureus cells were prepared as described by Gov et al. [18]. RAW 264.7 cells were pretreated with $100 \mu \mathrm{g} \mathrm{mL}^{-1}$ of the VA extracts for 6 hrs at $37^{\circ} \mathrm{C}$ before the phagocytic assay was performed. The phagocytic activities were determined as described by Shi et al. [23]. Briefly, macrophages $(5 \times$ $10^{6}$ cells) were coincubated with opsonized FITC-S. aureus $\left(5 \times 10^{8}\right.$ cells $)$ in $1 \mathrm{~mL}$ DPBS at $37^{\circ} \mathrm{C}$ for $30 \mathrm{~min}$. The macrophage cells were then washed 4 times with DPBS to eliminate the extracellular bacteria. The ingested FITCS. aureus was analyzed by Cytomic FC500 flow cytometer (Beckman Coulter, Fullerton, CA, U.S.A.).

2.9. Statistical Analysis. Differences between groups were compared using SAS software package version 9.1 (SAS Institute Inc., Cary, NC, U.S.A.). Statistical comparisons were analyzed by one-way analysis of variance (ANOVA), followed by Duncan's multiple-range test to locate differences. The results were presented as mean \pm standard error of mean (S.E.M.).

\section{Results}

3.1. Effect of VA Extracts on Cell Proliferation In Vitro. The effects of the VA extracts on murine macrophage and spleno- cyte proliferation were evaluated (Figure 1). The VAWB extract stimulated the proliferation of resting splenocytes and macrophages in a dose-dependent manner up to the highest concentration used $\left(150 \mu \mathrm{g} \mathrm{mL}^{-1}\right)$. The stimulating effect became significant at cocultured with $50 \mu \mathrm{g} \mathrm{mL}^{-1}$ of the VAWB extract for both cells when compared with blank as control. At concentration of $150 \mu \mathrm{g} \mathrm{mL}^{-1}$, the proliferation rate of murine macrophages and splenocytes for the VAWB extract were $171.5 \%$ and $132.4 \%$, respectively. Similar results were also found in the VACWS extracts. The VACWS extracts (100-150 $\left.\mu \mathrm{g} \mathrm{mL}^{-1}\right)$ induced the proliferation of splenocytes and macrophages in a dose-dependent manner. At concentration of $150 \mu \mathrm{g} \mathrm{mL}^{-1}$, the proliferation rates of murine macrophages and splenocytes for the VACWS extracts were $127.2 \%$ and $125.7 \%$, respectively.

3.2. Effect of VA Extracts on Cytokine Inhibition In Vitro. The effects of the VA extracts on cytokine inhibition by murine macrophages in the presence of LTA are shown in Figure 2. The production of proinflammatory cytokines (TNF- $\alpha$, IL-6) from the macrophages by adding LTA was significantly suppressed after being cocultured with the VA extracts in a dose-dependent manner up to the highest concentration used $\left(150 \mu \mathrm{g} \mathrm{mL}^{-1}\right)$. The inhibition effects of TNF- $\alpha$, IL-6, and IL-12 became significant in microphages cocultured with $100 \mu \mathrm{g} \mathrm{mL}^{-1}$ of either VABW or VACWS extracts when compared with LTA. Similar results were also found in peritoneal cells (Figure 3). The production of proinflammatory cytokines (TNF- $\alpha$, IL-6, IL-12 p40) from peritoneal cells by adding LTA was significantly suppressed after being cocultured with both VA extracts in a dosedependent manner.

3.3. Effect of VA Extracts on Phagocytic Activity In Vitro. The phagocytic activity of macrophages was investigated to confirm if it increased with the presence of the VA extracts. 


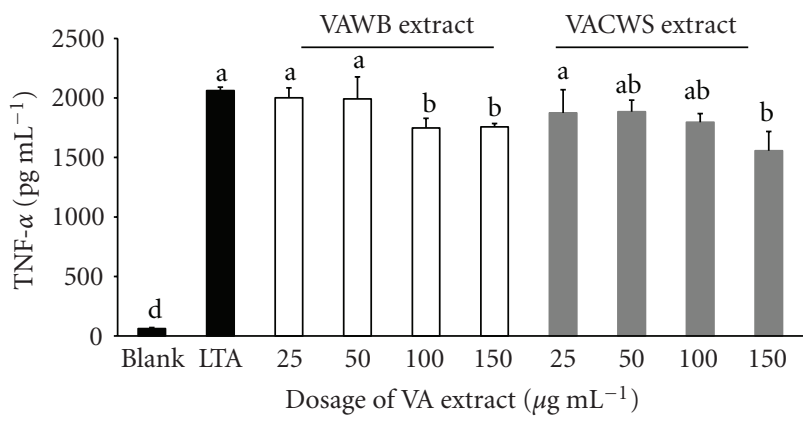

(A) TNF- $\alpha$

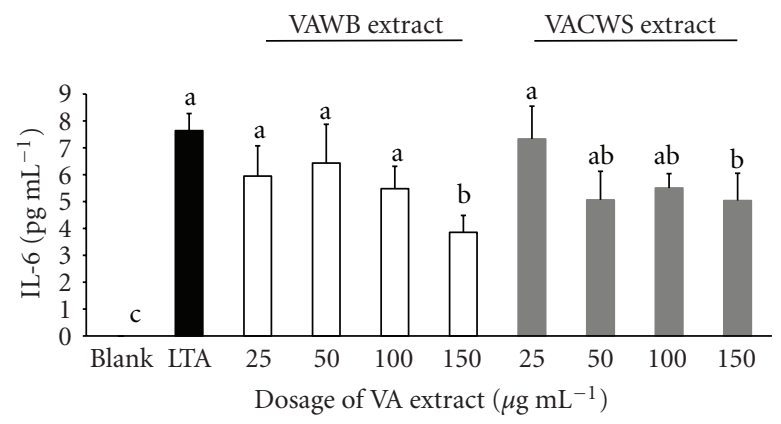

(B) IL-6

Figure 2: Inhibition of cytokine (A) TNF-alpha; (B) IL-6 secretion in RAW264.7 cells. Cells were stimulated with LTA (10 $\mu \mathrm{g} / \mathrm{mL})$ under the treatment of water boiled (VAWB) extract and cold water soaked (VACWS) extract within the range of $25 \mu \mathrm{g} \mathrm{mL} \mathrm{m}^{-1}$ to $200 \mu \mathrm{g} \mathrm{mL} \mathrm{m}^{-1}$. Values are mean \pm S.E.M. Asterisk denotes values that are significantly different from positive control group (LTA group). (a-c) Means within the same column without the same superscripts differ significantly $(P<.05, n=4)$.

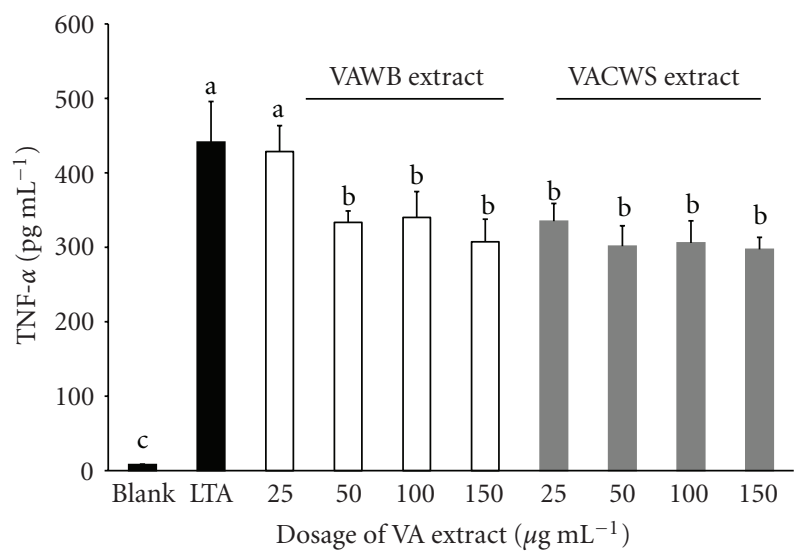

(A) TNF- $\alpha$

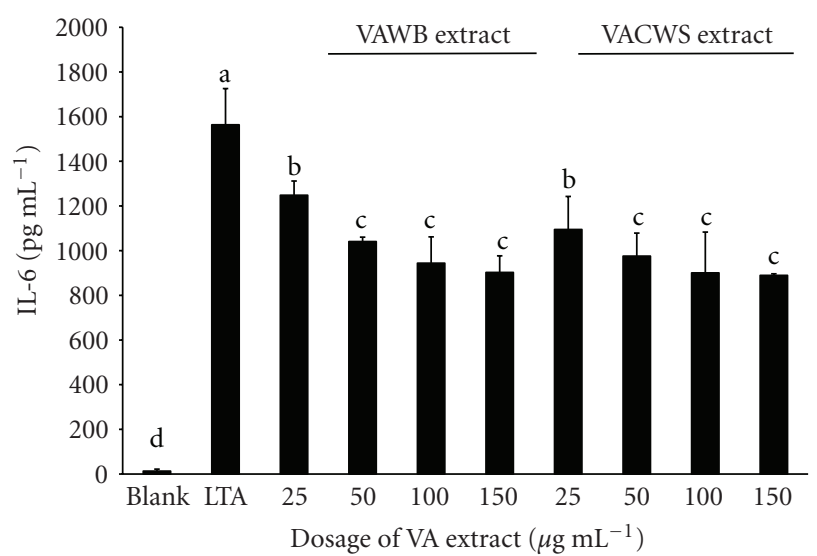

(B) IL-6

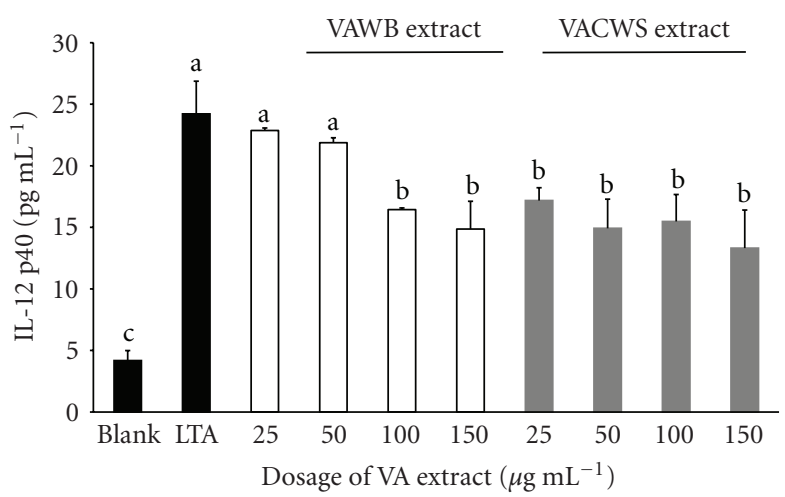

(C) IL-12 p40

FIgure 3: Inhibition of cytokine (A) TNF-alpha; (B) IL-6; (C) IL-12 p40 secretion in peritoneal cells. Cells were stimulated with LTA $\left(10 \mu \mathrm{g} \mathrm{mL}^{-1}\right)$ under the treatment of water-boiled (VAWB) extract and cold water-soaked (VACWS) extract within the range of $25 \mu \mathrm{g} \mathrm{mL}-1$ to $150 \mu \mathrm{g} \mathrm{mL}^{-1}$. Values are mean \pm S.E.M. Asterisk denotes values that are significantly different from positive control group (LTA group). $(\mathrm{a}-\mathrm{c})$ Means within the same column without the same superscripts differ significantly $(P<.05, n=4)$. 
Microphages treated by the VA extracts (Figure 4) demonstrated an enhanced phagocytic acidity against $S$. aureus when compared to the nontreated control macrophages. In particular, the VAWB extract-treated macrophages demonstrated 2.6-fold increases in phagocytic activity. These findings indicated that the VA extracts excited macrophages and further accelerated the antibacterial and phagocytic activities of macrophages.

\subsection{Effect of Oral Feeding of the VA Extracts and the VA Powder on Staphylococcus aureus-Infected Mice}

3.4.1. Inhibited S. aureus Activities by the VA Samples In Vivo. The numbers of $S$. aureus in PLF and kidneys of the mice treated by the VA samples (the VAWB extract, VACWS extract and the VA powder) were significantly lower than those of the control mice (Table 1). There were no significant differences among the different VA samples. Additionally, the effects of different dosages of the VA powder samples on S. aureus counts were studied (Table 2). Except for mice treated with $2.5 \mathrm{mg}$ of the VA powder, the concentrations of S. aureus in PLF and kidneys of the VA sample-pretreated mice were significantly lower than those from the control mice. There were no significant differences among different dosages. These results demonstrated that pretreatment of mice with the VA samples decreased significantly $S$. aureus number in the kidney and the PLF.

The organ weights of $S$. aureus-infected mice administrated with the different VA samples were also evaluated. Infected kidneys in the mice pretreated with 5 and $10 \mathrm{mg}$ of the VA powders weighed significantly less than those of the control mice (Tables 1 and 2), whereas infected kidneys in the VA extract-pretreated mice showed no significant difference with the control mice in weight.

3.4.2. Reduced Inflammatory Cytokines by the VA Samples. Blood samples from the VA sample-treated and subsequently $S$. aureus-infected mice and from the $S$. aureus-infected mice without pretreatment were both evaluated for levels of inflammatory cytokines in serum (Figure 5). The levels of IL- 6 and TGF- $\beta 1$ in serum were high for the mice infected with $S$. aureus without pretreatment. On the other hand, mice that were pretreated with the VAWB extract and the VA powder produced significantly lower levels of IL- 6 and TGF- $\beta 1$ than mice with no treatment. Interestingly, mice treated with the VACWS extract did not show any reduction in IL- 6 and TGF- $\beta 1$. The effects of different dosages of the VA powder on the production of inflammatory cytokines were also studied (Figure 6). Levels of IL-6 in serum were significantly downregulated for mice pretreated with all VA powder samples. The lowest levels of IL-6 were detected in the serum for the mice fed with $5 \mathrm{mg}$ or higher of the VA powder. A decrease of TGF- $\beta 1$ in serum was observed only when mice were treated with $10 \mathrm{mg}$ of the VA powder.

Proinflammatory cytokines are known important mediators in development of lethal sepsis. Our data indicated that the VA samples significantly inhibited the production of proinflammatory cytokines, which might effectively decrease the septic symptoms of mice.

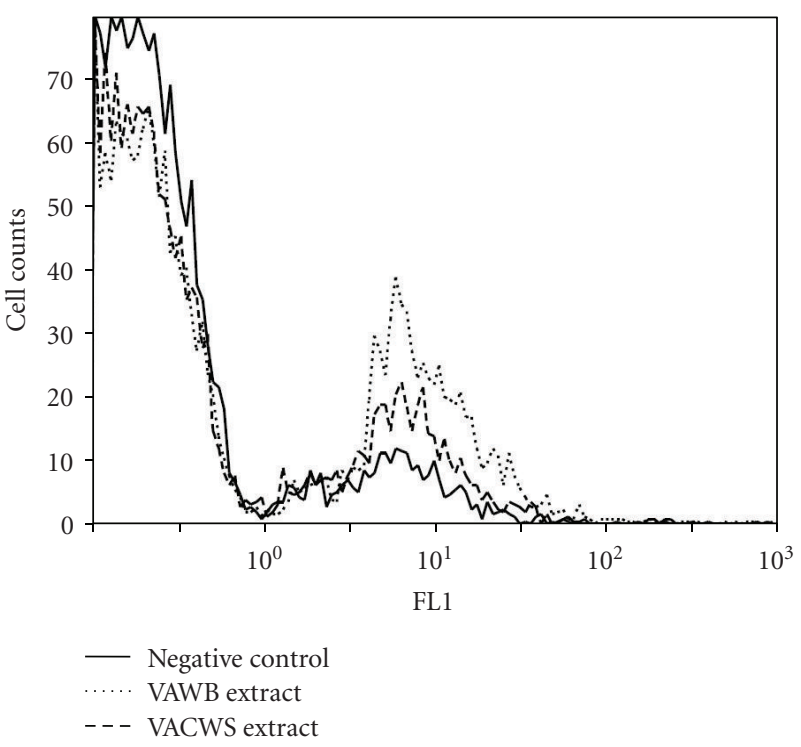

FIgURE 4: The VA extract enhance phagocytosis activities in heatkilled S. aureus-infected macrophages. Bold line: macrophages without pretreatment, dotted line: macrophages pre-treated with the VA water-boiled (VAWB) extract, dashed line: macrophages pre-treated with the VA cold water soaked (VACWS) extract. A representative of three separate assays is shown.

\section{Discussion}

Staphylococcus aureus is a virulent pathogen that has the ability to cause a variety of potentially life-threatening infections. Previous reports on the correlation VA extracts against $S$. aureus infection are rare. In this study, we demonstrated that the VA samples stimulated the proliferation of resting splenocytes and macrophages in a dose-dependent manner (Figure 1). The spleen is an ovoid secondary lymphoid organ that plays a major role in mounting immune responses to antigens in the blood stream [24]. Splenocytes, obtained from spleen, refer to T-cells, B-cells, nature killer cells, mononuclear cells, macrophages, and monocytes, which are characterized by the expression of cell surface or other markers [9]. Macrophages represent 3-7\% of leukocytes in blood and are necessary to the immune functions of lymph, spleen, and bone marrow [25]. Increasing macrophages enhance the immune functions. A couple of studies also reported that the bioactivity of the deer antler might act as an immune enhancer $[16,26]$.

Additionally, we confirmed that the VA extracts strongly inhibited the production of proinflammatory cytokine (Figures 2 and 3), such as TNF- $\alpha$, IL-6, and IL-12 p40, in response to in vitro stimulation with bacterial LTA in a dosedependent manner. These proinflammatory cytokines are produced by activated macrophages and other cell types. TNF- $\alpha$ is known to enhance the expression of accessory molecules involved in the adhesion of macrophages to the endothelium, increasing the possibility that other memory cells present in the circulatory system are guided to the inflammation site [27]. IL-12 is related to the differentiation of naïve $\mathrm{T}$ cells into $\mathrm{T}$ helper type 1 cells, which stimulates 
TABLE 1: Bacterial counts in organs and organ weights of S. aureus-infected mice administrated with the different VA samples.

\begin{tabular}{|c|c|c|c|c|}
\hline & \multicolumn{2}{|c|}{ Bacterial count } & \multicolumn{2}{|c|}{ Organ weight } \\
\hline & PLF* $\left(\log \mathrm{cfu} \mathrm{mL}^{-1}\right)$ & Kidney $\left(\log\right.$ cfu g $\left.{ }^{-1}\right)$ & Kidney (mg) & Spleen (mg) \\
\hline Water (negative control) & $0.0 \pm 0.0^{c}$ & $0.0 \pm 0.0^{c}$ & $245 \pm 7^{c}$ & $152 \pm 23^{b}$ \\
\hline Water (positive control) & $4.7 \pm 0.9^{\mathrm{a}}$ & $4.3 \pm 0.1^{\mathrm{a}}$ & $343 \pm 50^{\mathrm{a}}$ & $167 \pm 34^{\mathrm{a}}$ \\
\hline VACWS extract & $3.8 \pm 0.2^{b}$ & $4.1 \pm 0.7^{\mathrm{a}}$ & $318 \pm 44^{\mathrm{ab}}$ & $191 \pm 32^{\mathrm{a}}$ \\
\hline VAWB extract & $3.7 \pm 0.5^{\mathrm{b}}$ & $3.8 \pm 0.4^{\mathrm{ab}}$ & $299 \pm 46^{\mathrm{ab}}$ & $192 \pm 60^{\mathrm{a}}$ \\
\hline VA powder (500 $\mathrm{mg} \mathrm{kg}^{-1}$ mouse body weight) & $3.8 \pm 0.2^{\mathrm{b}}$ & $3.1 \pm 1.0^{\mathrm{b}}$ & $272 \pm 27^{b}$ & $169 \pm 20^{\mathrm{a}}$ \\
\hline
\end{tabular}

Values are mean \pm S.E.M.

Negative control means mice without i.p. S. aureus infection.

${ }^{\mathrm{a}-\mathrm{c}}$ Means within the same column and the same group without the same superscripts differ significantly $(P<.05, n=5)$.

* PLF: peritoneal lavage fluid.

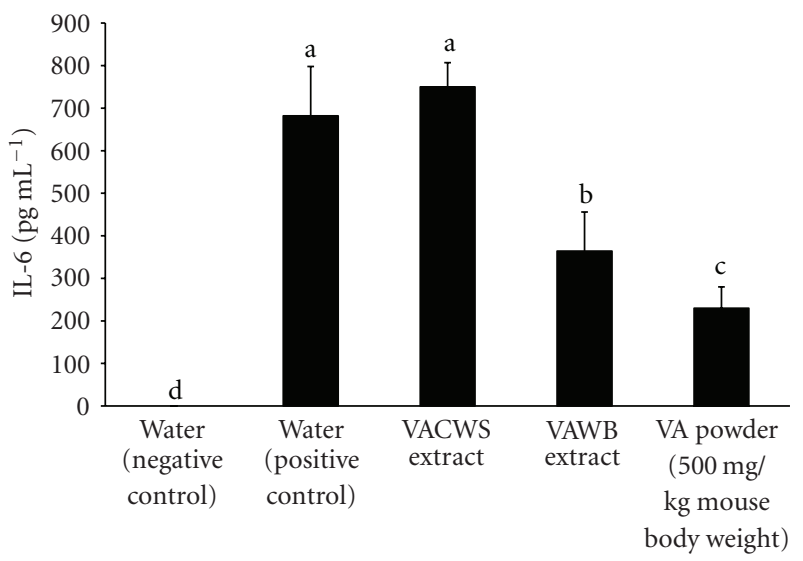

(A) IL-6

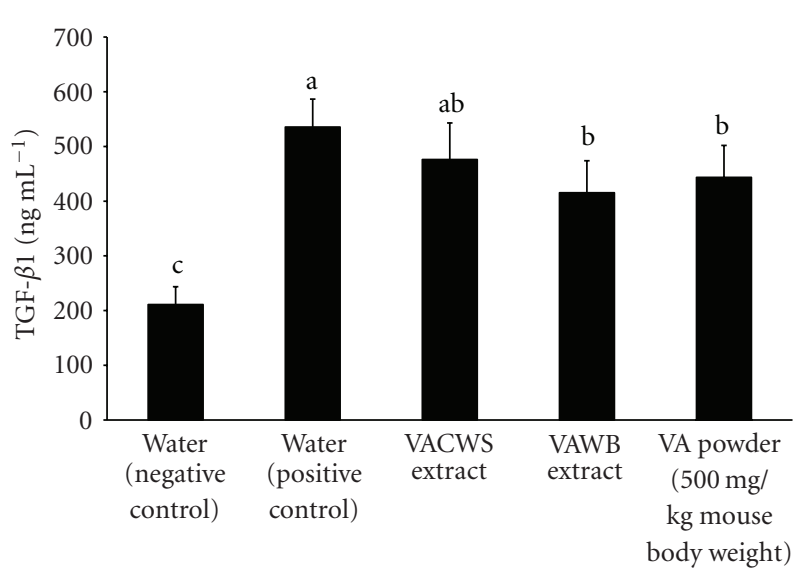

(B) TGF- $\beta 1$

FIGURE 5: Cytokine concentration in serum of S. aureus-infected mice (A) IL-6; (B) TGF- $\beta 1$. Values are mean \pm S.E.M. (a-c) Means within the same column without the same superscripts differ significantly $(P<.05, n=5)$.

the production of TNF- $\alpha$ from T and natural killer cells. The naïve $\mathrm{T}$ cells' activation and proliferation create an acquired immune response to the newly encountered pathogenic agent [22]. IL-6 is multifunctional cytokine involved in diverse biological processes, such as the growth factor for normal or neoplastic cells [28], the host response to enteric pathogens, and terminal differentiation of B lymphocytes [29]. However, increased concentrations of proinflammatory cytokines may attenuate excessive host inflammatory responses. Suh et al. [17] reported that the abundance of TNF- $\alpha$ in the arthritic joints provides evidence of its involvement in the disease pathology. Neutralization of TNF- $\alpha$ leads to reduce production of other inflammatory cytokines [30]. In response to in vitro stimulation with bacterial LTA for the downregulation of proinflammatory cytokines, we assumed that the VA extracts were able to deliver immune signals to macrophages and other cells and might possess anti-inflammatory properties.

Further animal tests on S. aureus-infected mice were also conducted to verify antiinfective effects of the VA samples. The mice that were treated with $5 \mathrm{mg}$ or higher of the VA powder for 28 days before being challenged with $S$. aureus exhibited the best protection against sepsis.
The numbers of $S$. aureus determined in the kidneys and PLF of $S$. aureus-infected mice were significantly higher than those found in the same organs of mice pretreated with the VA samples (Tables 2). Moreover, the highly enhanced phagocytic activity of macrophages (Figure 4) was further verified after in vitro treatment with the VA samples. Most phagocytosis is conducted by specialized cells, such as blood monocytes, neutrophils, and tissue macrophages. Monocyte/macrophage-mediated protection of animals was also demonstrated in S. aureus-induced endocarditis and sepsis models in different systems [25, 31]. Satorres et al. [32] indicated that phagocytic killing played an essential role to eliminate S. aureus in the host. The patients who were neutropenic or who have defects in polymorphonuclear leukocyte function suffered recurrent staphylococcal infections.

Major inflammatory cytokines such as IL-6 and TGF- $\beta 1$ in serum of $S$. aureus-infected mice were also studies. The excessive productions of IL- 6 and TGF- $\beta 1$ in serum were observed in $S$. aureus-infected mice not pretreated with the VA samples. Conversely, the levels of IL- 6 and TGF- $\beta 1$ in serum were suppressed for the mice pretreated with the VA samples (Figures 5 and 6). In accordance with our results, low levels of IL- 6 and TGF- $\beta 1$ in serum were also found in 
TABLE 2: Bacterial counts in organs and organ weights of $S$. aureus-infected mice administrated with the different dosages of the VA powder samples.

\begin{tabular}{|c|c|c|c|c|}
\hline \multirow[b]{2}{*}{ VA powder ( $\mathrm{mg} \mathrm{kg}^{-1}$ mouse body weight) } & \multicolumn{2}{|c|}{ Bacterial count } & \multicolumn{2}{|c|}{ Organ weight } \\
\hline & PLF* $\left(\log\right.$ cfu mL $\left.\mathrm{mL}^{-1}\right)$ & Kidney $\left(\log \mathrm{cfu} \mathrm{g}^{-1}\right)$ & Kidney (mg) & Spleen $(\mathrm{mg})$ \\
\hline Negative control & $0.0 \pm 0.0^{c}$ & $0.0 \pm 0.0^{c}$ & $245 \pm 7^{c}$ & $152 \pm 23^{\mathrm{b}}$ \\
\hline Positive control & $4.4 \pm 0.9^{\mathrm{a}}$ & $6.1 \pm 0.8^{\mathrm{a}}$ & $300 \pm 17^{a}$ & $198 \pm 20^{\mathrm{a}}$ \\
\hline 125 & $4.8 \pm 0.8^{\mathrm{a}}$ & $4.9 \pm 1.0^{\mathrm{b}}$ & $276 \pm 19^{\mathrm{a}}$ & $178 \pm 21^{\mathrm{a}}$ \\
\hline 250 & $3.5 \pm 0.6^{\mathrm{b}}$ & $4.7 \pm 0.9^{b}$ & $262 \pm 13^{b}$ & $183 \pm 25^{\mathrm{a}}$ \\
\hline 500 & $3.9 \pm 0.4^{\mathrm{b}}$ & $4.8 \pm 0.6^{\mathrm{b}}$ & $265 \pm 9^{b}$ & $176 \pm 22^{\mathrm{a}}$ \\
\hline
\end{tabular}

Values are mean \pm S.E.M.

${ }^{\mathrm{a}-\mathrm{c}}$ Means within the same column and the same group without the same superscripts differ significantly $(P<.05, n=8)$.

*PLF: peritoneal lavage fluid.

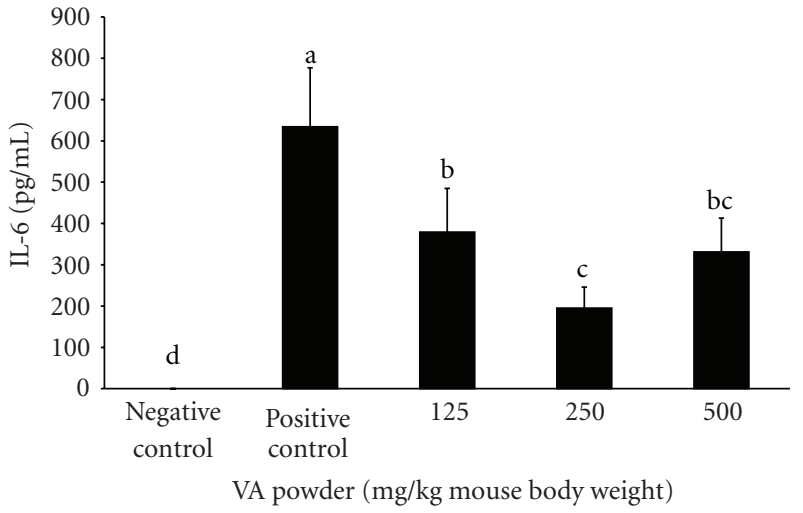

(A) IL-6

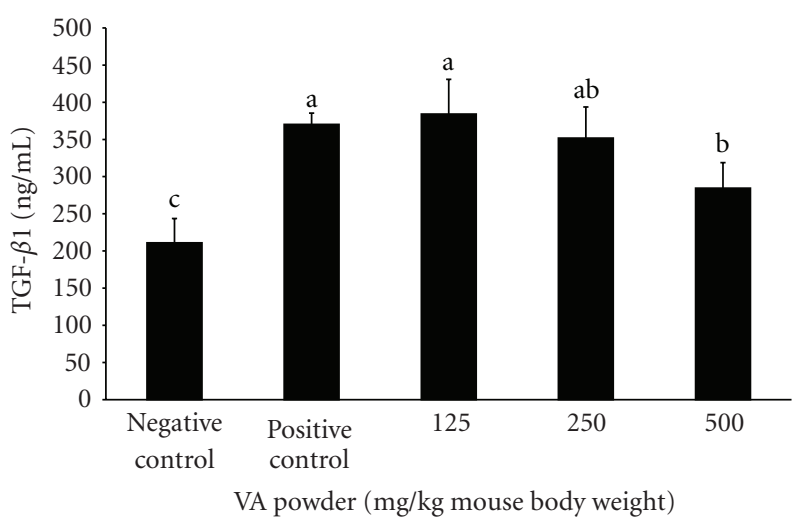

(B) TGF- $\beta 1$

FIGURE 6: Cytokine concentration in serum of S. aureus-infected mice administrated with different dosages of the VA powders (A) IL-6; (B) TGF- $\beta 1$. Values are mean \pm S.E.M. (a-c) Means within the same column without the same superscripts differ significantly $(P<.05, n=8)$.

vaccinated mice [33]. Yao et al. [34] indicated that cytokine expression in the tissues correlated with leukocyte migration into the affected tissue and with evidence of progressive tissue damage. Early and intense production of IL-6 corresponded to a rapid worsening of articular lesions [35].

Furthermore, IL-6 and TGF-beta are recognized as Thelper 17 (Th17)-inducing cytokines. Th17 cytokines such as IL-17 have been associated with several conditions, including airway inflammation, rheumatoid arthritis, and inflammatory bowel disease [36]. IL-6 not only enhances production of Th17 [37], but also suppresses the expression of regulatory $\mathrm{T}$ cell (Treg) differentiation, favoring expression of the Th17 cells [38]. Although the role of TGF- $\beta$ in Th17 development is unclear, a couple of studies have indicated that TGF- $\beta$ is necessary for human Th17 development $[39,40]$. A recent study has shown that TGF- $\beta$, IL- $1 \beta$, and IL- 6 are required for Th17 production [41]. In this respect, the VA samples protected mice from sepsis-induced symptoms by inhibiting the synthesis of inflammatory cytokines. Additionally, TGF$\beta$ appeared to block the activation of lymphocytes and monocyte-derived phagocytes. Downregulation of TGF- $\beta$ for mice pretreated with the VA samples might enhance phagocytic activity of macrophages [42].
This study also confirmed that the preparation methods significantly affected the bioactive properties of the VA samples. Our results indicated that the VA powder, dehydrated by lyophilization, might preserve more bioactive components showing a better preventive effect against $S$. aureus than the other VA extract samples. Batchelder [13] indicated that therapeutical substances were destroyed in the heating phase of most drying methods. Yudin and Dubryakov [43] also suggested that boiling antler tips destroyed their bioactive potential. Besides heating temperature of extraction and dehydration, the solvents used in extraction of the VA samples also played an important role for preserving bioactive components. The quality of deer antler has often been evaluated by the amount of gangliosides, a sialic acidcontaining glycosphingolipid [44]. Ganglioside GM311 and phophatidylcholines with saturated fatty acyl chains $[9,45]$ might be components related to the proliferation of lymphocytes. Calder et al. [46] also demonstrated the role of fatty acids in the modulation of immune responses. Many other substances from VA such as chondroitin sulfate have also been identified and claimed to contain active components. Chondroitin sulfate, a potent anti-inflammatory agent, is the most prominent glycosaminoglycans in velvet antler tissue. 
This component has been used by arthritis patients with excellent results. Water extracting methods (such as cold water-soaked extraction and water-boiled extraction) might only extract water soluble bioactive substances from VA (carbohydrates, hexosamines, hydronyprolines, mucopolysacchride, sialic acids, uronic acids, etc.). However, it might be difficult to obtain water insoluble fatty acids (prostaglandins, phospholipids, glycolipids, gangliosides, etc.), which might also possess the therapeutic effects.

\section{Conclusion}

This study has demonstrated the protective mechanisms induced by the VA samples in $S$. aureus-infected animals. The protective mechanisms of the VA samples might include an immune enhancer and a proinflammatory cytokine suppressor. Pretreatment of the VA samples stimulated the proliferation of splenocytes and macrophages enhancing the immune functions. The first protective effect against $S$. aureus given by the VA samples was the upregulated phagocytic activity of monocytes/macrophages. The second protective effect was the reduced synthesis of sepsis-inducing proinflammatory cytokines at a later stage of bacterial infections. Both enhancing phagocytic activity and inhibiting proinflammatory cytokines played important roles for the VA samples in the clearance of $S$. aureus in the infected mice. The VA powder, dehydrated by lyophilization, might preserve more bioactive components and show a better preventive effect against $S$. aureus than the other VA extract samples. This report is thought to be the first to evaluate the effects of velvet antler (VA) of Formosan sambar deer and its extracts on the antiinfective activity against pathogenic Staphylococcus aureus.

\section{Acknowledgment}

The authors wish to thank Council of Agriculture and the National Science Council in Taiwan for their support of this research.

\section{References}

[1] J. P. W. Chan, H. Y. Tsai, C. F. Chen, K. C. Tung, and C. C. Chang, "The reproductive performance of female Formosan sambar deer (Cervus unicolor swinhoei) in semi-domesticated herds," Theriogenology, vol. 71, no. 7, pp. 1156-1161, 2009.

[2] R. Zhou, J. Wang, S. Li, and Y. Liu, "Supercritical fluid extraction of monoamine oxidase inhibitor from antler velvet," Separation and Purification Technology, vol. 65, no. 3, pp. 275281, 2009.

[3] L. Kardell and S. Kallman, "Heavy metals in antlers of roe deer from two Swedish forests, 1968-1983," Ambio, vol. 15, no. 4, pp. 232-235, 1986.

[4] G. J. Jhon, S. Y. Park, S. Y. Han, S. Lee, Y. Kim, and Y. S. Chang, "Studies of the chemical structure of gangliosides in deer antler, Cervus nippon," Chemical and Pharmaceutical Bulletin, vol. 47, no. 1, pp. 123-127, 1999.

[5] K. M. Ko, T. T. Yip, and S. W. Tsao, "Epidermal growth factor from deer (Cervus elaphus) submaxillary gland and velvet antler," General and Comparative Endocrinology, vol. 63, no. 3, pp. 431-440, 1986.

[6] J. W. Newbrey and W. J. Banks, "Ultrastructural changes associated with the mineralization of deer antler cartilage," American Journal of Anatomy, vol. 166, no. 1, pp. 1-17, 1983.

[7] Y. J. Li, T. H. Kim, H. B. Kwak, Z. H. Lee, S. Y. Lee, and G. J. Jhon, "Chloroform extract of deer antler inhibits osteoclast differentiation and bone resorption," Journal of Ethnopharmacology, vol. 113, no. 2, pp. 191-198, 2007.

[8] M. Allen, K. Oberle, M. Grace, A. Russell, and A. J. Adewale, "A randomized clinical trial of elk velvet antler in rheumatoid arthritis," Biological Research for Nursing, vol. 9, no. 3, pp. 254261, 2008.

[9] K. H. Kim, E. J. Lee, K. Kim, S. Y. Han, and G. J. Jhon, "Modification of concanavalin A-dependent proliferation by phosphatidylcholines isolated from deer antler, Cervus elaphus," Nutrition, vol. 20, no. 4, pp. 394-401, 2004.

[10] H. S. Kim and H. K. Lim, "Inhibitory effects of velvet antler water extract on morphine-induced conditioned place preference and DA receptor supersensitivity in mice," Journal of Ethnopharmacology, vol. 66, no. 1, pp. 25-31, 1999.

[11] S. K. Kang, K. S. Kim, S. I. Kim, K. H. Chung, IN. S. Lee, and C. H. Kim, "Immunosuppressive activity of deer antler extracts of Cervus korean TEMMINCK var. mantchuricus Swinhoe, on type II collagen-induced arthritis," In Vitro Cellular and Developmental Biology, vol. 42, no. 3-4, pp. 100-107, 2006.

[12] H. B. Xu, Y. Z. Li, X. G. Chen, X. B. Sun, and B. X. Wang, "Study on the anti-aging action of phosphate of pilose antler," Pharmacology and Clinics of Chinese Materia Medica, vol. 8, pp. 29-31, 1992.

[13] H. J. Batchelder, "Velvet antler: a literature review," Health Supplement Retailer, vol. 5, pp. 40-51, 1999.

[14] J. S. Church, Velvet Antler: Its Historical Medical Use, Performance Enhancing Effects and Pharmacology, Elk Tech International Research Centre, Calgary, Canada, 1999.

[15] B. X. Wang, "Advances in research of chemistry, pharmacology and clinical application of pilose antler," in Proceedings of the International Deer Science and Deer Products, B. X. Wang, Q. L. Zhou, and Y. Wang, Eds., Changchun, China, 1996.

[16] J. S. Suh, J. S. Eun, J. N. So, J. T. Seo, and G. J. Jhon, "Phagocytic activity of ethyl alcohol fraction of deer antler in murine peritoneal macrophage," Biological and Pharmaceutical Bulletin, vol. 22, no. 9, pp. 932-935, 1999.

[17] S. J. Suh, K. S. Kim, A. R. Lee et al., "Prevention of collageninduced arthritis in mice by Cervus korean TEMMINCK var. mantchuricus Swinhoe," Environmental Toxicology and Pharmacology, vol. 23, no. 2, pp. 147-153, 2007.

[18] Y. Gov, A. Bitler, G. Dell'Acqua, J. V. Torres, and N. Balaban, "RNAIII inhibiting peptide (RIP), a global inhibitor of Staphylococcus aureus pathogenesis: structure and function analysis," Peptides, vol. 22, no. 10, pp. 1609-1620, 2001.

[19] J. Cohen, "The immunopathogenesis of sepsis," Nature, vol. 420, no. 6917, pp. 885-891, 2002.

[20] L. Zhao, B. P. Ji, B. Li, F. Zhou, J. H. Li, and Y. C. Luo, "Immunomodulatory effects of aqueous extract of velvet antler (Cervus elaphus Linnaeus) and its simulated gastrointestinal digests on immune cells in vitro," Journal of Food and Drug Analysis, vol. 17, no. 4, pp. 282-317, 2009.

[21] X. Zhang, R. Goncalves, and D. M. Mosser, "The isolation and characterization of murine macrophages," Current Protocols in Immunology, no. 83, pp. 14.1.1-14.1.14, 2008.

[22] W. S. Hong, H. C. Chen, Y. P. Chen, and M. J. Chen, "Effects of kefir supernatant and lactic acid bacteria isolated from kefir 
grain on cytokine production by macrophage," International Dairy Journal, vol. 19, no. 4, pp. 244-251, 2009.

[23] L. Shi, K. Takahashi, J. Dundee et al., "Mannose-binding lectin-deficient mice are susceptible to infection with Staphylococcus aureus," Journal of Experimental Medicine, vol. 199, no. 10, pp. 1379-1390, 2004.

[24] T. J. Kindt, R. A. Goldsby, and B. A. Osborne, "Cells and organs of immune system," in Kuby Immunology, T. J. Kindt, R. A. Goldsby, and B. A. Osborne, Eds., pp. 23-51, W. H. Freeman and Company, New York, NY, USA, 6th edition, 2007.

[25] J. Y. Ahn, I. S. Choi, J. Y. Shim et al., "The immunomodulator ginsan induces resistance to experimental sepsis by inhibiting Toll-like receptor-mediated inflammatory signals," European Journal of Immunology, vol. 36, no. 1, pp. 37-45, 2006.

[26] S. Y. Han, S. H. Cho, S. Y. Kim, J. T. Seo, S. J. Moon, and G. J. Jhon, "Monoacetyldiglycerides as new $\mathrm{Ca}^{2+}$ mobilizing agents in rat pancreatic acinar cells," Bioorganic and Medicinal Chemistry Letters, vol. 9, no. 1, pp. 59-64, 1999.

[27] G. Vinderola, G. Perdigón, J. Duarte, E. Farnworth, and C. Matar, "Effects of the oral administration of the exopolysaccharide produced by Lactobacillus kefiranofaciens on the gut mucosal immunity," Cytokine, vol. 36, no. 5-6, pp. 254-260, 2006.

[28] E. K. Ng, N. Panesar, W. E. Longo et al., "Human intestinal epithelial and smooth muscle cells are potent producers of IL6," Mediators of Inflammation, vol. 12, no. 1, pp. 3-8, 2003.

[29] M. E. Goodrich and D. W. McGee, "Effect of intestinal epithelial cell cytokines on mucosal B-cell IgA secretion: enhancing effect of epithelial-derived IL- 6 but not TGF- $\beta$ on IgA+ B cells," Immunology Letters, vol. 67, no. 1, pp. 11-14, 1999.

[30] C. Haworth, F. M. Brennan, D. Chantry, M. Turner, R. N. Maini, and M. Feldmann, "Expression of granulocytemacrophage colony-stimulating factor in rheumatoid arthritis: regulation by tumor necrosis factor- $\alpha$," European Journal of Immunology, vol. 21, no. 10, pp. 2575-2579, 1991.

[31] M. Verdrengh and A. Tarkowski, "Role of macrophages in Staphylococcus aureus-induced arthritis and sepsis," Arthritis and Rheumatism, vol. 43, no. 10, pp. 2276-2282, 2000.

[32] S. E. Satorres, L. E. Alcaráz, E. Cargnelutti, and M. S. Di Genaro, "IFN- $\gamma$ plays a detrimental role in murine defense against nasal colonization of Staphylococcus aureus," Immunology Letters, vol. 123, no. 2, pp. 185-188, 2009.

[33] L. Lin, A. S. Ibrahim, X. Xu et al., "Th1-Th17 cells mediate protective adaptive immunity against Staphylococcus aureus and Candida albicans infection in mice," PLoS Pathogens, vol. 5, no. 12, Article ID e1000703, pp. 1-10, 2009.

[34] L. Yao, J. W. Berman, S. M. Factor, and F. D. Lowy, "Correlation of histopathologic and bacteriologic changes with cytokine expression in an experimental murine model of bacteremic Staphylococcus aureus infection," Infection and Immunity, vol. 65, no. 9, pp. 3889-3895, 1997.

[35] M. Puliti, C. Von Hunolstein, F. Bistoni, P. Mosci, G. Orefici, and L. Tissi, "Influence of interferon- $\gamma$ administration on the severity of experimental group B streptococcal arthritis," Arthritis and Rheumatism, vol. 43, no. 12, pp. 2678-2686, 2000.

[36] J. Witowski, K. Ksiązek, and A. Jörres, "Interleukin-17: a mediator of inflammatory responses," Cellular and Molecular Life Sciences, vol. 61, no. 5, pp. 567-579, 2004.

[37] E. V. Acosta-Rodriguez, L. Rivino, J. Geginat et al., "Surface phenotype and antigenic specificity of human interleukin 17producing T helper memory cells," Nature Immunology, vol. 8, no. 6, pp. 639-646, 2007.
[38] S. L. Traves and L. E. Donnelly, "Th17 cells in airway diseases," Current Molecular Medicine, vol. 8, no. 5, pp. 416-426, 2008.

[39] E. Volpe, N. Servant, R. Zollinger et al., "A critical function for transforming growth factor- $\beta$, interleukin 23 and proinflammatory cytokines in driving and modulating human T17 responses," Nature Immunology, vol. 9, no. 6, pp. 650-657, 2008.

[40] N. Manel, D. Unutmaz, and D. R. Littman, "The differentiation of human T-17 cells requires transforming growth factor- $\beta$ and induction of the nuclear receptor ROR $\gamma \mathrm{t}$," Nature Immunology, vol. 9, no. 6, pp. 641-649, 2008.

[41] S. Burgler, N. Ouaked, C. Bassin et al., "Differentiation and functional analysis of human T17 cells," Journal of Allergy and Clinical Immunology, vol. 123, no. 3, pp. 588-595, 2009.

[42] K. W. Kim, K. H. Song, J. M. Lee et al., "Effects of TGF $\beta 1$ and extracts from Cervus korean TEMMINCK var. mantchuricus Swinhoe on acute and chronic arthritis in rats," Journal of Ethnopharmacology, vol. 118, no. 2, pp. 280-283, 2008.

[43] A. M. Yudin and Y. L. Dubryakov, "A guide for the preparation and storage of uncalcified male antlers as a medicinal raw material," in Reindeer Antlers, Academy of Sciences of the USSR, Vladivostok: Far East Science Center, 1974.

[44] K. W. Kim, K. H. Song, J. M. Lee et al., "Effects of TGF $\beta 1$ and extracts from Cervus korean TEMMINCK var. mantchuricus Swinhoe on acute and chronic arthritis in rats," Journal of Ethnopharmacology, vol. 118, no. 2, pp. 280-283, 2008.

[45] N. N. Anita and C. Rui, "Phosphatidylcholine participates in the interaction between macrophages and lymphocytes," American Journal of Physiology, vol. 278, no. 3, pp. C554-C560, 2000.

[46] P. C. Calder, J. A. Bond, S. J. Bevan, S. V. Hunt, and E. A. Newsholme, "Effect of fatty acids on the proliferation of concanavalin A-stimulated rat lymph node lymphocytes," International Journal of Biochemistry, vol. 23, no. 5-6, pp. 579$588,1991$. 


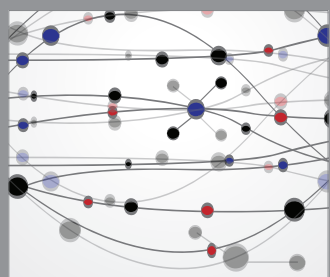

The Scientific World Journal
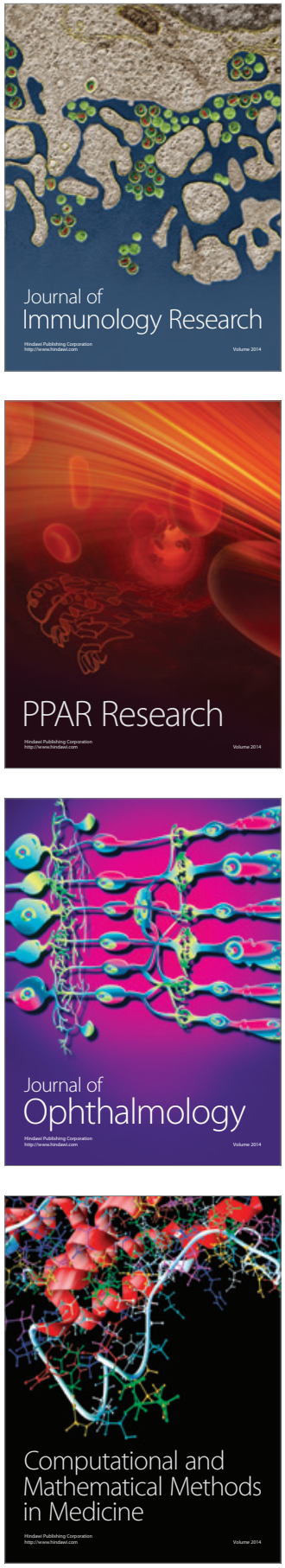

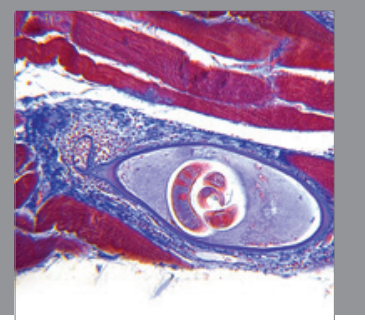

Gastroenterology

Research and Practice
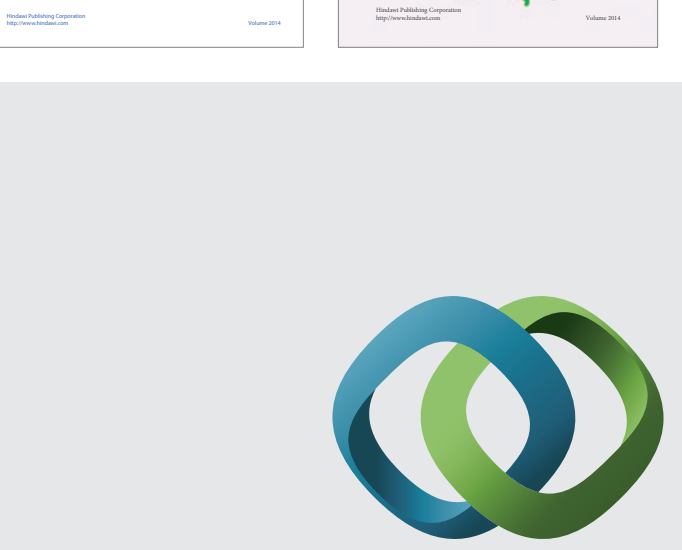

\section{Hindawi}

Submit your manuscripts at

http://www.hindawi.com
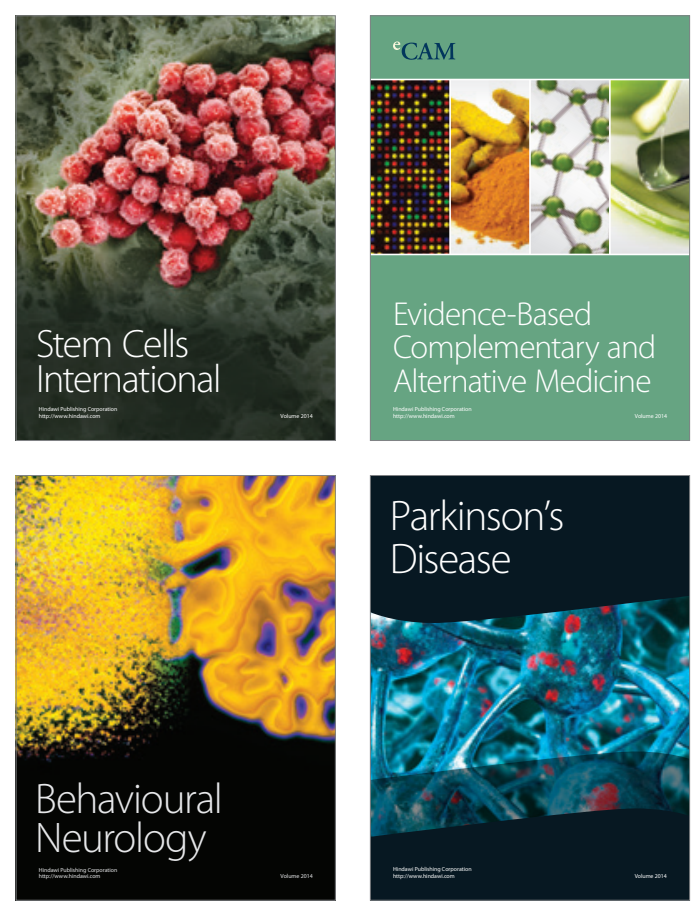

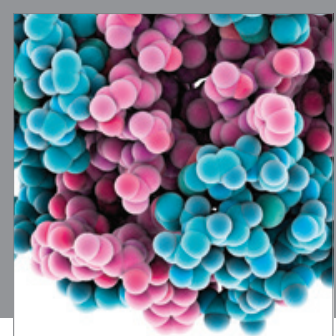

Journal of
Diabetes Research

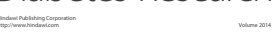

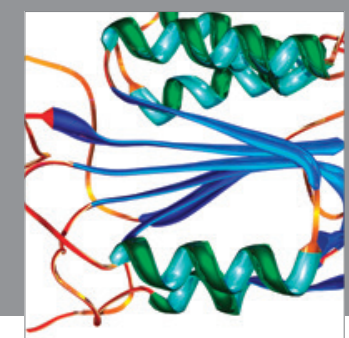

Disease Markers
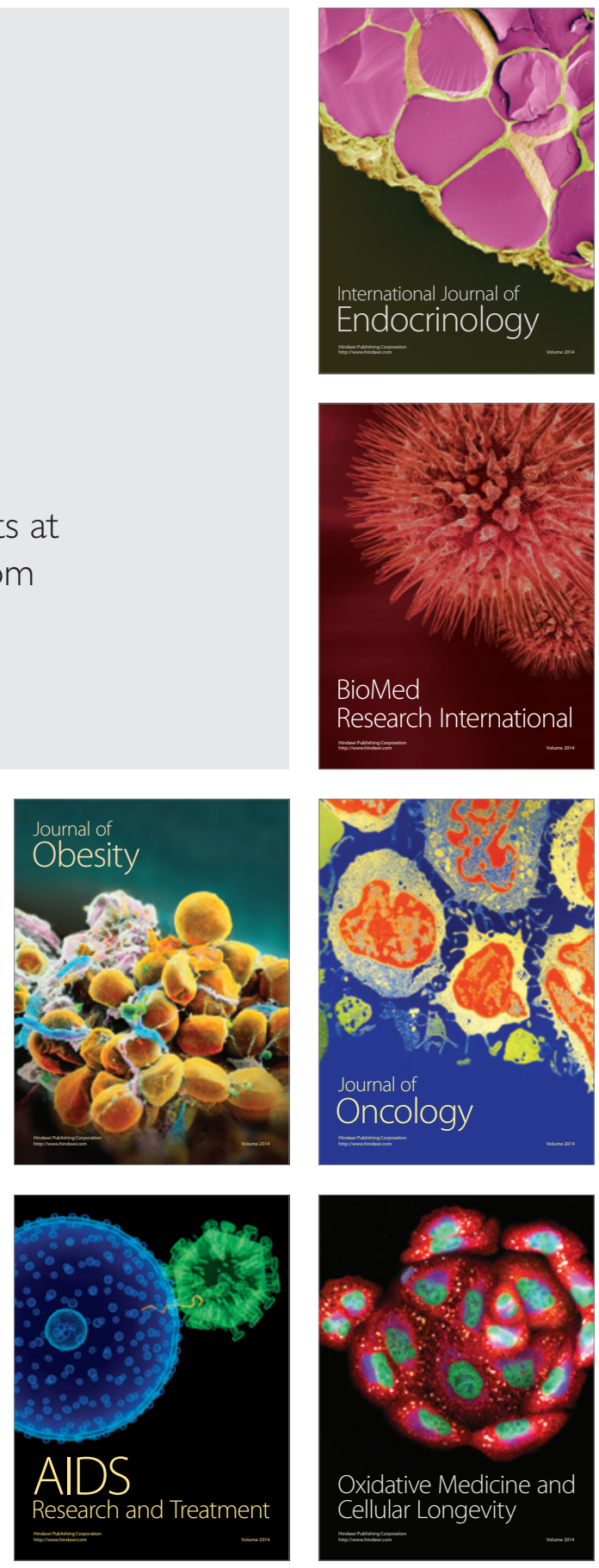